\title{
CXCL1 wt Allele
}

National Cancer Institute

\section{Source}

National Cancer Institute. CXCL1 wt Allele. NCI Thesaurus. Code C49763.

Human CXCL1 wild-type allele is located within $4 \mathrm{q} 21$ and is approximately $14 \mathrm{~kb}$ in length.

This allele, which encodes growth-regulated alpha protein, plays a role in

polymorphonuclear leukocyte chemotaxis and inflammation. CXCL1 also affects

endothelial cells involved in angiogenesis or ang iostasis in an autocrine fashion, and central nervous system function. 